\title{
Hubungan Pengetahuan tentang Covid-19 dengan Tingkat Kepatuhan Anak Remaja Menjalankan Protokol Kesehatan di Indonesia
}

\section{The Relationship between Knowledge about Covid-19 and Adolescents Compliance with Health Protocols in Indonesia}

\author{
Insiyatul Hikmah $^{1}$, Hanifatur Rosyidah ${ }^{2}$, Kartika Adyani $^{3}$ \\ Program Studi Kebidanan, Universitas Islam Sultan Agung Semarang, Indonesia
}

\section{ARTICLE INFO}

\section{Article history}

Received date 19 May 2021

Revised date

14 Jun 2021

Accepted date

09 Nov 2021

Keywords:

Adolescents knowledge;

Covid-19;

Health protocols.

Kata kunci:

Pengetahuan remaja;

Covid-19;

Protokol kesehatan.

\author{
ABSTRACT/ ABSTRAK
}

\begin{abstract}
The lack of knowledge about Covid-19 that teenagers have will cause teenagers to not comply with health protocols in Indonesia so that the spread of Covid-19 becomes uncontrollable. The purpose of this study is to determine the relationship between knowledge about Covid-19 and the level of compliance of adolescents in carrying out health protocols in Indonesia. The research design method was quantitative with a crosssectional approach. The research subjects were adolescents in Indonesia with 400 respondents conducted on 29 October - 11 November 2020. The sampling technique used was snowball sampling with research instruments using a questionnaire with the chisquare test. There is a relationship between adolescent knowledge about covid-19 and handwashing ( $\mathrm{p}$-value $=0,000$ ), there is a relationship between adolescent knowledge about Covid-19 using masks ( $\mathrm{p}$-value $=0,000$ ) and there is between adolescent knowledge about Covid-19 and social distancing (p-value=0,006). It is hoped that the results of this study can be used as information material regarding the relationship between knowledge about Covid-19 and the level of compliance of adolescents in carrying out health protocols in Indonesia, for adolescents, it is hoped that they can increase knowledge about Covid-19 by watching the news on TV, reading newspapers, social media and from health workers, for further researchers, it is hoped that they need to conduct research with qualitative methods and use more varied variables related to knowledge about Covid-19 with the level of compliance of adolescents in carrying out health protocols in Indonesia.
\end{abstract}

\begin{abstract}
Minimnya pengetahuan tentang Covid-19 yang dimiliki remaja akan menyebabkan remaja tidak patuh terhadap protokol kesehatan di Indonesia sehingga penyebaran Covid19 menjadi tidak terkendali. Tujuan dalam penelitian ini untuk mengetahui hubungan pengetahuan tentang Covid-19 dengan tingkat kepatuhan anak remaja menjalankan protokol kesehatan di Indonesia. Desain penelitian kuantitatif dengan pendekatan cross sectional. Subjek penelitian adalah remaja di Indonesia berjumlah 400 responden yang dilaksanakan pada tanggal 29 Oktober - 11 November 2020. Teknik pengambilan sampel yang digunakan adalah snowball sampling dengan instrumen penelitian menggunakan kuesioner dengan uji chi-square. Ada hubungan antara pengetahuan remaja tentang Covid-19 dengan kepatuhan cuci tangan ( $p$-value $=0,000)$, ada hubungan antara pengetahuan remaja tentang Covid-19 dengan kepatuhan menggunakan masker ( $p$ value $=0,000)$ dan ada antara pengetahuan remaja tentang Covid-19 dengan kepatuhan melakukan social distancing $(p$-value $=0,006)$. Diharapkan hasil penelitian ini dapat menjadi bahan informasi mengenai hubungan pengetahuan tentang Covid-19 dengan tingkat kepatuhan anak remaja menjalankan protokol kesehatan di Indonesia, bagi remaja, diharapkan dapat meningkatkan pengetahuan tentang Covid-19 dengan cara melihat berita di TV, membaca koran, media sosial dan dari tenaga kesehatan, bagi peneliti selanjutnya, diharapkan perlu melakukan penelitian dengan metode kualitatif serta menggunakan variabel lebih bervariasi yang berhubungan dengan pengetahuan tentang Covid-19 dengan tingkat kepatuhan anak remaja menjalankan protokol kesehatan di Indonesia.
\end{abstract}

Corresponding Author:

Insiyatul Hikmah

Program Studi Kebidanan, Universitas Islam Sultan Agung Semarang, Indonesia

Email: insiyatulhikmah@gmail.com 


\section{PENDAHULUAN}

Coronavirus-19 telah dinyatakan sebagai pandemi dunia oleh WHO (WHO, 2020). Virus dan penyakit ini diketahui pertama kali dikota Wuhan, Cina sejak Desember 2019. Sampai dengan per tanggal 21 Maret 2020, jumlah kasus penyakit ini mencapai angka 275,469 jiwa yang tersebar di 166 negara, termasuk Indonesia (Kementerian Kesehatan RI, 2020).

Kasus pertama Covid-19 di Indonesia diumumkan pada tanggal 2 Maret 2020. Sementara pada tanggal 8 Mei 2020 tercatat 12.776 kasus dan 930 kematian terjadi di 34 provinsi yang ada di Indonesia (Nugraheni, 2020). Indonesia mengumumkan pada tanggal 05 juli 2020 adanya penambahan kasus sebanyak 1,07. jumlah total kasus infeksi Covid-19 di Indonesia menjadi sebanyak 63.749 kasus selain update kasus infeksi, jumlah pasien sembuh juga mengalami peningkatan sebanyak 886 kasus menjadi 29.105 pasien sedangkan jumlah pasien meninggal menjadi sebanyak 3.171 atau bertambah 82 kasus kematian. Sehingga menjadikan Indonesia sebagai negara dengan jumlah kasus terbanyak di ASEAN melewati Singapura (Habibie, dalam Natalia, 2020).

Presiden Republik Indonesia menyatakan status penyakit ini menjadi tahap Tanggap Darurat pada tanggal 17 Maret 2020. Presiden juga mengeluarkan Keputusan Presiden No. 7 Tahun 2020 tentang Gugus Tugas Percepatan Penanganan. Gugus tugas ini betujuan untuk meningkatkan ketahanan nasional dibidang kesehatan, dan kemampuan dalam mencegah, mendeteksi dan merespon terhadap Covid-19 (Kementerian Kesehatan RI, 2020).

Virus corona bisa menyerang siapa saja, termasuk ibu hamil atau ibu menyusui, remaja serta bayi dan anak-anak. Munculnya gejala Covid-19 disebabkan oleh reaksi tubuh untuk melawan virus corona. Guna pencegahan Covid19 Indonesia melakukan beberapa kebijakan salah satunya PSBB. Pembatasan Sosial Berskala besar (PSBB) sudah diterapkan di Indonesia di beberapa daerah yang padat penduduk seperti Jakarta, Jawa Barat, Jawa Timur. Namun angka yang terinfeksi masih meningkat, karena masih banyaknya masyarakat yang tidak mematuhi peraturan PSBB (Buana, 2020). Garda terdepan dalam menangani kasus Covid-19 adalah para dokter dan tenaga medis, namun untuk mengatasi permasalahan yang terjadi saat ini harus dari semua elemen di masyarakat termasuk para generasi muda. Semua warga negara di Indonesia punya peran dan punya tugas dalam membantu menghadapi Covid-19, begitu pula untuk generasi muda (Kementerian Kesehatan RI, 2020).

Peran generasi muda ini sangat besar, diharapkan para generasi muda bisa berperan sebagai agent of change. Genarasi muda seperti remaja merupakan sosok yang muda, dinamis, penuh energi, optimis, dan mendorong terjadinya transformasi dunia ini ke arah yang lebih. Masa remaja adalah suatu masa peralihan dari masa kanak-kanak menuju kemasa dewasa, dengan ditandai individu telah mengalami perkembanganperkembangan atau pertumbuhan-pertumbuhan yang sangat pesat di segala bidang yang memengaruhi mereka dalam berprilaku. Pada masa remaja, individu cenderung suka meniru sikap orang lain dan labil sehingga memengaruhi pola pikir mereka dalam menjalankan peraturan yang ada. Individu juga memiliki ketertarikan dengan hal-hal yang lebih penting sehingga mereka tidak terjerumus ke hal-hal yang tidak diinginakan. Remaja pun menjadi lebih mandiri serta bertanggung jawab yang berdampak terhadap kepatuhan mereka dalam berprilaku sehingga dapat membantu pemerintah dalam memutus rantai penyebaran Covid-19 dengan mematuhi protokol yang ada (Hurlock, 2016).

Remaja juga rentan terinfeksi Covid-19. Selain itu, remaja juga dapat mengalami keparahan akibat virus corona apabila memiliki kondisi kronis bawaan seperti obesitas. Hal tersebut dijelaskan pada penelitian Shekerdemian et al. (2020), mereka mengungkapkan bahwa lebih dari $80 \%$ pasien memiliki kondisi yang parah mulai dari penyakit imun, obesitas, diabetes, serta paru kronis (Shekerdemian et al., 2020), mereka mengungkapkan bahwa lebih dari $80 \%$ pasien memiliki kondisi yang parah melai dari penyakit imun, obesitas, diabetes, sera penyakit paru kronis.

Remaja yang terpapar Covid-19 memiliki kemungkinan yang sama seperti menularkan ke orang lain. Sebuah studi yang dirilis dalam jurnal Pediatri menunjukan, 2.134 anak muda di Cina menjadi penyebab peneyebara virus corona, dengan lebih dari $90 \%$ memiliki penyakit ringan hingga sedang bahkan tanpa gejala (WHO, 2020). Pelaksanaan protokol kesehatan dapat mengurangi resiko timbulnya masalah bagi kesehatan remaja. Protokol kesehatan yang dilakukan adalah tetap di rumah (stay at home), menjaga jarak dan fisik dengan jarak minimal 1 meter dengan orang lain, menggunakan masker, membersihkan tangan secara teratur dengan cuci tangan pakai sabun dengan air mengalir, menjaga dan meningkatkan daya tahan tubuh dengan menerapkan perilaku hidup bersih dan sehat (PHBS) (Kementerian Kesehatan RI, 2020). 
Remaja di Indonesia sebanyak $60 \%$ memiliki pengetahuan dan pemahaman yang baik terhadap Covid-19 baik itu remaja perempuan maupun remaja laki-laki (Habibie dalam Natalia, 2020). Selama masa isolasi dan karantina wilayah yang berkepanjangan juga, anak remaja lebih rentan terhadap kecemasan, stres, dan mengalami perilaku kesehatan yang beresiko (Tim COVID-19 IDAI, 2020). Oleh karena itu perlu melakukan himbauan sesering mungkin serta melakukan tidakan-tindakan untuk pencegahan Covid-19, menjelaskan dan mengingatkan selalu pentingnya stay at home, menjadi relawan bagi sekitar yang membutuhkan dukungan makanan dan obat dengan tetap menjaga prinsip pembatasan sosial, serta mematuhi protokol kesehatan (Annas, 2020). Selain dengan melakukan hal-hal tersebut, remaja juga diharapkan melakukan perilaku yang mendukung protokol kesehatan.

Berdasarkan hal tersebut, peneliti tertarik untuk melakukan penelitian untuk mengetahui hubungan pengetahuan tentang covid-19 dengan tingkat kepatuhan anak remaja di Indonesia dalam menjalankan protokol kesehatan di kehidupan sehari-hari.

\section{METODE}

Penelitian ini merupakan penelitian kuantitatif, desain penelitian yang digunakan adalah survey online dengan studi deskriptif korelasi dengan pendekatan cross sectional. Populasi dalam penelitian ini ialah anak remaja di indonesia yang berjumlah 67.268.917 jiwa. Sampel dalam penelitian sebanyak 400 responden yang dilakukan selama 2 minggu (29 Oktober-11 November 2020) dengan teknik pengambilan sampel snowball sampling. Kriteria inklusi dalam penelitian ini yaitu anak remaja berusia 11-20 tahun di Indonesia, remaja yang bersedia menjadi responden dan menjawab kuesioner dan remaja yang mempunyai Smart Phone. Variabel independen dalam penelitian ini adalah pengetahuan remaja tentang Covid-19, dan variabel dependen penelitian ini adalah tingkat kepatuhan anak remaja menjalankan protokol kesehatan di Indonesia.

Jenis penelitian yang digunakan kuantitatif dengan pendekatan cross sectional. Teknik pengumpulan data primer pada peneltian ini yaitu dengan melakukan penyebaran kuesioner secara online menggunakan google form yang berisi 30 item pertanyaan yang disebarluaskan kepada seluruh remaja di Indonesia melalui teman, saudara, guru serta melalui media online seperti Whatsapp, Facebook, Twitter, dan Instagram.

Data dianalisis dengan metode statistik non parametrik karena data berskala kategorik. Peneliti menggunakan uji chi-square untuk menentukan adakah hubungan yang signifikan secara statistik antara dua variabel yaitu variabel independen dengan variabel dependen yang berskala data nominal dan ordinal, di anggap ada hubungan bila $p$-value $<0,05$.

Penelitian ini sudah melalui proses Ethical Clearance dan telah disetujui oleh Komisi Biomedika Penelitian Kedokteran/Kesehatan Fakultas Kedokteran Universitas Islam Sultan Agung dengan Nomor. 317/X/2020/Komisi Bioetik.

\section{HASIL}

Tabel 1. Karakteristik Responden

\begin{tabular}{lrr}
\hline \multicolumn{1}{c}{ Karakteristik } & f & \multicolumn{1}{c}{$\%$} \\
\hline Jenis kelamin & & \\
$\quad$ Laki-laki & 90 & 22,5 \\
$\quad$ Perempuan & 310 & 77,5 \\
Umur & & \\
Remaja Awal (11-13 th) & 6 & 1,5 \\
$\quad$ Remaja Madya (14-16 th) & 57 & 14,3 \\
Remaja Akhir (17-20 th) & 337 & 84,3 \\
\hline
\end{tabular}

Berdasarkan tabel 1 menunjukan bahwa sebagian besar responden berada pada kategori remaja akhir berusia 17-20 tahun yaitu sebanyak $337(84,3 \%)$.

Tabel 2. Distribusi Frekuensi berdasarkan Pengetahuan Covid-19

\begin{tabular}{lcc}
\hline Pengetahuan Covid-19 & f & \% \\
\hline Baik & 296 & 74,0 \\
Kurang & 104 & 26,0 \\
\hline
\end{tabular}

Berdasarkan tabel 2 diketahui bahwa sebagian responden mempunyai pengetahuan baik yaitu 296 responden $(74,0 \%)$ dan mempunyai pengetahuan kurang yaitu 104 responden $(26,0 \%)$. 
Tabel 3. Distribusi Frekuensi Berdasarkan Tingkat Kepatuhan Anak Remaja Menjalankan Protokol Kesehatan

\begin{tabular}{lrrrrrr}
\hline \multirow{2}{*}{ Tingkat Kepatuhan } & \multicolumn{2}{c}{$\begin{array}{c}\text { Melakukan } \\
\text { Cuci Tangan }\end{array}$} & \multicolumn{2}{c}{$\begin{array}{c}\text { Menggunakan } \\
\text { Masker }\end{array}$} & \multicolumn{2}{c}{$\begin{array}{c}\text { Melakukan } \\
\text { Social Distancing }\end{array}$} \\
\cline { 2 - 8 } & f & \% & f & \% & F & \% \\
\hline Tidak Patuh & 8 & 2,0 & 71 & 17,8 & 5 & 1,3 \\
Patuh & 392 & 9,8 & 329 & 82,3 & 395 & 98,8 \\
\hline
\end{tabular}

Berdasarkan tabel 3 menunjukan distribusi frekuensi responden berdasarkan cuci tangan remaja di Indonesia diketahui bahwa sebagian besar responden patuh 392 responden $(98,0 \%)$ dalam cuci tangan, patuh dalam menggunakan masker yaitu 329 responden $(82,3 \%)$, kepatuhan social distancing diketahui bahwa sebanyak 395 responden $(98,8 \%)$.

Tabel 4. Hubungan antara Pengetahuan tentang Covid-19 dengan Kepatuhan Anak Remaja Menjalankan Protokol Kesehatan di Indonesia

\begin{tabular}{|c|c|c|c|c|c|c|c|c|c|c|c|c|}
\hline \multirow{3}{*}{$\begin{array}{c}\text { Pengetahuan } \\
\text { tentang Covid-19 }\end{array}$} & \multicolumn{4}{|c|}{$\begin{array}{l}\text { Melakukan } \\
\text { cuci tangan }\end{array}$} & \multicolumn{4}{|c|}{$\begin{array}{l}\text { Menggunakan } \\
\text { masker }\end{array}$} & \multicolumn{4}{|c|}{$\begin{array}{l}\text { Melakukan social } \\
\text { distancing }\end{array}$} \\
\hline & \multicolumn{2}{|c|}{$\begin{array}{l}\text { Tidak } \\
\text { patuh }\end{array}$} & \multicolumn{2}{|c|}{ Patuh } & \multicolumn{2}{|c|}{$\begin{array}{l}\text { Tidak } \\
\text { patuh }\end{array}$} & \multicolumn{2}{|c|}{ Patuh } & \multicolumn{2}{|c|}{$\begin{array}{l}\text { Tidak } \\
\text { Patuh } \\
\end{array}$} & \multicolumn{2}{|c|}{ Patuh } \\
\hline & f & $\%$ & f & $\%$ & f & $\%$ & f & $\%$ & f & $\%$ & f & $\%$ \\
\hline Kurang & 7 & 1,8 & 97 & 24,3 & 34 & 8,5 & 70 & 17,5 & 4 & 1,3 & 100 & 25,0 \\
\hline Baik & 1 & 0,3 & 295 & 73,8 & 37 & 9,3 & 259 & 64,8 & 1 & 0,3 & 295 & 73,8 \\
\hline Total & 8 & 2,0 & 392 & 98,0 & 71 & 17,8 & 329 & 82,3 & 5 & 1,3 & 395 & 98,8 \\
\hline$P$ & & & & 0,000 & & & & 0,000 & & & & 0,000 \\
\hline OR & & & & 0,047 & & & & 0,294 & & & & 0,085 \\
\hline
\end{tabular}

Pada tabel 4 menujukkan ada hubungan antara pengetahuan remaja tentang Covid-19 dengan kepatuhan cuci tangan ( $p$-value $=0,000)$, ada hubungan antara pengetahuan remaja tentang Covid-19 dengan kepatuhan menggunakan masker (p-value $=0,000), \quad$ dan ada antara pengetahuan remaja tentang Covid-19 dengan kepatuhan melakukan social distancing ( $p$ value $=0,006$ ).

\section{PEMBAHASAN}

Hasil penelitian menunjukan bahwa sebagian besar responden berada pada kategori remaja akhir berusia 17-20 tahun yaitu sebanyak 337 (84,3\%). Remaja akhir atau istilah asing late adolecence merupakan remaja berusia 17-20 tahun. Berbeda dengan penelitian yang dilakukan di Mojokerto sebagian besar responden $(69,4 \%)$ merupakan remaja madya (16-18 tahun) (Anggreni, 2020). Pada penelitian ini mayoritas responden berjenis kelamin perempuan yaitu sebanyak 310 responden $(77,5 \%)$. Hal ini sesuai dengan penelitian yang dilakukan di Depok bahwa sebagian besar responden berjenis kelamin perempuan sebanyak $190 \quad(66,7 \%)$ (Wiranti, Sriatmi, and Kusumastuti, 2020).

Pada penelitian ini diketahui bahwa sebagian responden mempunyai pengetahuan baik yaitu 296 responden $(74,0 \%)$ dan mempunyai pengetahuan kurang yaitu 104 responden (26,0\%). Hal ini sesuai dengan penelitian yang dilakukan di Kabupaten Wonosobo yang menunjukkan pengetahuan tentang Covid 19 berada pada kategori Baik $(90 \%)$ dan hanya $10 \%$ berada pada kategori cukup (Purnamasari, et al., 2020).

Berdasarkan hasil analisa data berdasarkan perilaku cuci tangan, menggunakan masker, dan kepatuhan social distancing, diketahui bahwa sebagian besar remaja di Indonesia patuh menjalankan perilaku tersebut. Menurut peneliti, hal ini dapat dipengaruhi dari tingkat pengetahuan remaja Indonesia.

Tingkat pengetahuan seseorang dipengaruhi oleh beberapa faktor diantaranya yaitu pendidikan, media massa atau media informasi, sosial bidaya, ekonomi, lingkungan, pengalaman, pekerjaan serta usia (Fitriani and Andriyani, 2015). Pengetahuan merupakan salah satu hal yang penting diperhatikan dalam rangka penanganan khususnya dalam mencegah transmisi dan menekan penyebaran virus (Law, S., Leung, A. W., \& Xu, 2020). Pengetahuan yang dimiliki ini akan memengaruhi seseorang dalam mengambil keputusan terhadap suatu permasalahan yang dihadapi (Purnamasari, et al., 2020).

Penelitian yang dilakukan di Wuhan menyatakan bahwa skor pengetahuan yang tinggi memengaruhi sikap dan perilaku yang di ambil responden (Xu, et al., 2020). Sebagian besar pengetahuan yang dimiliki seseorang berasal dari pendidikan baik formal dan informal, 
pengalaman pribadi maupun orang lain, lingkungan, serta media massa (Utami, Mose and Martini, 2020). Hal ini terbukti pada hasil penelitian dimana mayoritas responden yang memiliki pengetahuan baik lebih patuh melaksanakan protokol kesehatan.

Usia memengaruhi terhadap daya tangkap dan pola pikir seseorang, dengan bertambahnya usia individu, daya tngkap dan pola pikir seseorang akan lebih berkembang, sehingga penegetahua yang diperolehnya semakin baik (Notoatmodjo, 2012). Pada usia 17-20 tahun adalah usia yang matang dimana seseorang pada usia tersebut akan mempunyai pertimbangan dalam menangkap informasi dan mempunyai daya pikir yang baik. Berdasarkan hasil penelitian yang sudah dilakukan didapatkan mayoritas responden berada pada kategori remaja akhir yang berusia 17-20 tahun dimana mayoritas responden memilki pengetahuan baik 296 responden $(74,0 \%)$. Hasil penelitian ini tidak sesuai dengan penelitian yang dilakukan oleh Wulandari, et al., (2020) yang menjelaskan bahwa tidak ada hubungan yang signifikan antara usia dengan penegtahuan masyarakat di Kalimantan Selatan mengenai pencegahan Covid19 (Wulandari, et al., 2020)

Hasil analisa data diketahui bahwa responden yang memiliki pengetahuan baik memiliki kecenderungan untuk patuh melakukan cuci tangan sebanyak 295 (73,8\%). Dari hasil uji statistik menggunakan uji chi-square hal ini menunjukkan terdapat hubungan yang signifikan antara pengetahuan tentang Covid-19 dengan kepatuhan cuci tangan remaja di Indonesia $p$ value $=0,000 \quad(<0,05)$. Nilai Odds Ratio didapatkan 0,047 menunjukkan responden yang memiliki pengetahuan kurang, beresiko 0,047 kali tidak patuh melakukan cuci tangan. Hal ini sesuai dengan penelitian yang dilakukan di Jakarta menunjukkan $60,0 \%$ responden dengan pengetahuan baik patuh dalam melakukan cuci tangan dan terdapat hubungan yang signifikan antara pengetahuan dan kepatuhan melakukan cuci tangan dengan nilai $p$-value $=0,018(<0,05)$ (Sumardi, 2019).

Berdasarkan hasil analisa data diketahui bahwa responden dengan pengetahuan baik memiliki kecenderungan untuk patuh dalam menggunakan masker $(64,8 \%)$. Hasil uji statistik menggunakan uji chi-square menujukkan terdapat hubungan yang signifikan antara pengetahuan dan kepatuhan responden menggunakan masker dengan nilai $p$ value $=0,000 \quad(<0,05)$. Nilai Odds Ratio didapatkan 0,294 menunjukkan responden yang memiliki pengetahuan kurang, beresiko 0,294 kali tidak patuh menggunakan masker. Serupa dengan penelitian yang dilakukan oleh Sari and'Atiqoh, (2020) bahwa hasil pengetahuan masyarakat dengan kepatuhan penggunaan masker sebesar 0,004 ( $p$-value $<0,05)$ yaitu ada hubungan antara pengetahuan masyarakat dengan kepatuhan penggunaan masker sebagai upaya pencegahan penyakit Covid-19 di Kecamatan Ngronggah, Yogyakarta (Sari and 'Atiqoh, 2020).

Berdasarkan hasil analisa data menunjukkan responden dengan pengetahuan baik memiliki kecenderungan untuk patuh dalam melakukan social distancing $(73,8 \%)$. Terdapat hubungan yang signifikan antara pengetahuan dengan kepatuhan responden melakukan social distancing dengan nilai $p$-value $=0,006(<0,05)$. Nilai Odds Ratio 0,085 menunjukkan responden yang memiliki pengetahuan kurang, beresiko 0,085 kali tidak patuh melakukan social distancing. Hal ini sejalan dengan penelitian yang dilakukan di Depok bahwa terdapat hubungan yang signifikan antara tingkat pengetahuan dan kepatuhan melaksanakan social distancing dengan nilai $p$-value $=0,014 \quad(<0,05)$ (Wiranti, Sriatmi, and Kusumastuti, 2020).

\section{SIMPULAN}

Mayoritas responden memiliki pengetahuan baik tentang Covid-19. Terdapat hubungan antara pengetahuan remaja tentang Covid-19 dengan kepatuhan melakukan cuci tangan, menggunakan masker dan melakukan social distancing oleh remaja di Indonesia.

Diharapkan hasil penelitian ini dapat menjadi bahan informasi mengenai hubungan pengetahuan tentang Covid-19 dengan tingkat kepatuhan anak remaja menjalankan protokol kesehatan di Indonesia, bagi remaja, diharapkan dapat meningkatkan pengetahuan tentang Covid19 dengan cara melihat berita di TV, membaca koran, media sosial dan dari tenaga kesehatan, bagi peneliti selanjutnya, diharapkan perlu melakukan penelitian dengan metode kualitatif serta menggunakan variabel lebih bervariasi yang berhubungan dengan pengetahuan tentang Covid19 dengan tingkat kepatuhan anak remaja menjalankan protokol kesehatan di Indonesia. 


\section{DAFTAR PUSTAKA}

Anggreni, D., \& Safitri, C. A. (2020). Hubungan Pengetahuan Remaja tentang COVID-19 dengan Kepatuhan Dalam Menerapkan Protokol Kesehatan di Masa New Normal. Hospital Majapahit (Jurnal Ilmiah Kesehatan Politeknik Kesehatan Majapahit Mojokerto), 12(2), 134-142.

Annas. (2020). Surat Edaran Sekretaris Jenderal Kementerian Pertanian No 1056/SE/RC 10/03/2020 tentang Strategi dalam Pencegahan dan perlindungan Covid-19. Jakarta.

Buana, D. R. (2020). Analisis Perilaku Masyarakat Indonesia dalam Menghadapi Pandemi Virus Corona (Covid-19) dan Kiat Menjaga Kesejahteraan Jiwa', SALAM: Jurnal Sosial dan Budaya Syar-i, 7(3). doi: 10.15408/sjsbs.v7i3.15082.

Fitriani, N. L. and Andriyani, S. (2015). Hubungan Antara Pengetahuan Dengan Sikap Anak Usia Sekolah Akhir (10-12 Tahun) Tentang Makanan Jajanan Di Sd Negeri Ii Tagog Apu Padalarang Kabupaten Bandung Barat Tahun 2015. Jurnal Pendidikan Keperawatan Indonesia, 1(1), p. $7 . \quad$ doi: 10.17509/jpki.v1i1.1184.

Hurlock. (2016). Psikologi Perkembangan: Suatu Pendekatan Sepanjang Rentang Kehidupan. Jakarta : Erlangga.

Kementerian Kesehatan RI. (2020). Protokol Kesehatan bagi masyarakat di tempat dan fasilitas umum dalam rangka pencegahan pengendalian corona virus disease 2019 (covid-19). Jakarta.

Kementerian Kesehatan RI. (2020). Keputusan Menteri Kesehatan Republik Indonesia Tentang Panduan Pencegahan dan Pengendalian COVID-19. https://covid19.kemkes.go.id/protokolcovid-19/kmk-no-hk-01-07-menkes-4132020-ttg-pedoman-pencegahan-danpengendalian-covid-19

Law, S., Leung, A. W., \& Xu, C. (2020). Severe acute respiratory syndrome (SARS) and coronavirus disease-2019 (COVID-19): From causes to preventions in Hong Kong. International Journal of Infectious Diseases, 94, 156-163.

Notoatmodjo, S. (2012). Promosi Kesehatan dan Perilaku Kesehatan (edisi revisi 2012), Jakarta: Rineka Cipta.

Natalia, R. N., Malinti, E., \& Elon, Y. (2020, May). Kesiapsiagaan Remaja Dalam Menghadapi Wabah Covid-19. In NHIHC:
Nani Hasanuddin International Health Conference (Vol. 15, No. 2, pp. 107-111).

Nugraheni. (2020). Sebaran 13.112 Kasus Covid19 di 34 Provinsi, DKI Jakarta. https://nasional.kompas.com/read/2020/05/ 09/03300061/update-8-mei-sebaran-

12.112-kasus-covid-19-di-34-provinsi-dkijakarta.

Purnamasari, I., \& Raharyani, A. E. (2020). Tingkat pengetahuan dan perilaku masyarakat Kabupaten Wonosobo tentang Covid-19. Jurnal Ilmiah Kesehatan, 10(1), 33-42.

Sari, D. P. and 'Atiqoh, N. S. (2020). Hubungan antara pengetahuan masyarakat dengan kepatuhan penggunakan masker sebagai upaya pencegahan penyakit COVID-19 di Ngronggah', INFOKES Journal, 10(1). http://ojs.udb.ac.id/index.php/infokes/articl e/view/850.

Shekerdemian, L. S. et al. (2020). Characteristics and Outcomes of Children with Coronavirus Disease 2019 (COVID-19) Infection Admitted to US and Canadian Pediatric Intensive Care Units', JAMA Pediatrics. doi: 10.1001/jamapediatrics.2020.1948.

Sumardi, B. (2019). Hubungan Pengetahuan Dan Sikap Dengan Kepatuhan Perawat Dalam Melakukan Penerapan Standar Cuci Tangan', Jurnal keperawatan, 2(3). pp. 133-140.

Tim COVID-19 IDAI. (2020). Protokol Tatalaksana Covid-19. Jakarta.

Utami, R. A., Mose, R. E. and Martini, M. (2020) 'Pengetahuan, Sikap dan Keterampilan Masyarakat dalam Pencegahan COVID-19 di DKI Jakarta. Jurnal Kesehatan Holistic. doi: $10.33377 / \mathrm{jkh} . v 4 \mathrm{i} 2.85$.

WHO. (2020). World Health Organization. Rational use of personal protectiveequipment for coronavirus disease (COVID-19). Geneva: World Health Organization.

Wiranti, W., Sriatmi, A., \& Kusumastuti, W. (2020). Determinan kepatuhan masyarakat Kota Depok terhadap kebijakan pembatasan sosial berskala besar dalam pencegahan COVID-19. Jurnal Kebijakan Kesehatan Indonesia: JKKI, 9(3), 117-124.

Wulandari, A. et al. (2020). Hubungan Karakteristik Individu dengan Pengetahuan tentang Pencegahan Coronavirus Disease 2019 pada Masyarakat di Kalimantan Selatan. Jurnal Kesehatan Masyarakat 
Indonesia, 15(1), p. 42. doi: 10.26714/jkmi.15.1.2020.42-46.

Xu, Z., Shi, L., Wang, Y., Zhang, J., Huang, L., Zhang, C., ... \& Wang, F. S. (2020).
Pathological findings of COVID-19 associated with acute respiratory distress syndrome. The Lancet medicine, 8(4), 420-422. 